\title{
Concentric Model Diversification Model Of Farming Female Business Based On Information Technology
}

\author{
Muslichah Erma Widiana \\ Economic and Business Department \\ University of Bhayangkara Surabaya \\ Surabaya, Indonesia \\ Dewi Amartani \\ Economic and Business Department \\ University of Bhayangkara Surabaya \\ Surabaya, Indonesia
}

\begin{abstract}
Land optimization activities were carried out in 5 provinces, namely West Java, Banten, Central Java, DIY and East Java. The existence of a group of women farmers in East Java in the use of land for agriculture, such as fruit and vegetables, should get a response for their follow-up considering the potential activities of women farmer groups. Most of the population in East Java earn a living as farmers and farm labourers. The landowners each cover an area of $350 \mathrm{~m} 2$. The income of women farmers and farm labourers is uncertain depending on the season. It could be when the season is not good they work out of town. So many strategies are poor farmers (farmers with a narrow monthly income of Rp.750,000, and farm labourers earning Rp. 30,000 per day), even though they have to work harder. Research with the title of Information Technology Center Concentric Diversification Model of Information Technology Women. The aim is to minimize disparities in the village. With the use of knowledge and technology, poverty and disparity can be minimized and even eliminated. This study provides macro benefits for stakeholders, namely HR supplying raw materials, farm women who morph into entrepreneurship so that domestic and foreign consumers will get superior products in high-quality regions.
\end{abstract}

Keywords: Technology Diversification, SME's, Relational Benefit

\section{BACKGROUND}

Farmer women groups are one of the women's organizations that have the same livelihood. This group unites women into one organization from agriculture, plantations and fishermen. This peasant women's organization is present considering that Indonesia is one of the agrarian countries with the majority of its livelihoods originating from agriculture, food crop subsector 17.73 million households, livestock 12.77 million households, livestock 12, 97 million households, fisheries 1.19 million household aquaculture, fishing activities 0.86 million households, forestry 6.78 million households and agriculture 1, 08 million households

Agricultural activities are often identified with men, so some general agricultural groups are mostly followed by men. Seeing the reality in the field that those who play not only men form a special group for women. The farmer group according to Sri Nuryani (2012), is an important point to run and translate the concept of farmers' rights in a policy strategy, and a feasible program in a unified whole and as a container for transformation and development into operational steps. Important farmer groups as a forum for fostering farmers incorporated in it, so as to facilitate agricultural development 
The female farmer group from Blitar, East Java, Indonesia is one of the cities famous for its agricultural sector. Blitar Regency is connected by relatively easy to reach roads, most of which are already asphalt roads. The existence of a group of women farmers in the city of Blitar in the utilization of land for agriculture such as fruit and vegetables is worth getting a response to follow-up considering the potential activities of women farmer groups in Blitar. Most of the population in the village of Pasirharjo Kec. Talun Blitar Regency works as a farmer and farm labourer, due to the land and temperature conditions that support Blitar district for agriculture Nearly 2,515 ha are farmland owned by landholders, each covering an area of $350 \mathrm{~m} 2$.

The income of women farmers and farm labourers is uncertain depending on the season, this is because their agricultural systems depend on nature. Moreover, the current season cannot be predicted. So if the natural temperature is good then the income they earn can be said to be enough to be used to finance their subsistence needs. It could be that when the season is not good they work outside the city, seek income outside the agricultural sector, work as a builder, some even use the strategy of tying the belt tighter. They prefer to reduce the intensity of their consumption normally in a day of eating 3 times, but they eat twice a day. So many strategies are poor farmers (farmers with a narrow monthly income of Rp.750,000, and farm labourers earning Rp. 30,000 per day), even though they have to work harder. Impacts occur in village disparities. On the other hand, if agricultural products are managed with knowledge and technology poverty and disparities can be minimized and even eliminated.

To realize Small and Medium Enterprises (SMEs) and Cooperative membership in women farmers who are able to manage the results of land to be produced further, as well as improve marketing, the use of technology, especially e-commerce is needed by SMEs to promote their products widely. By SMEs from agricultural production using information technology to promote all of their products across geographical boundaries. The use of information technology for SMEs can be used to improve relational marketing, among others, can provide flexibility in the promotion, enable delivery to customers faster, send and receive offers quickly and economically, and support paperless fast transactions and improved marketing performance characterized by growth sales. Therefore, the application of a relational marketing strategy using technology facilities is very important for SMEs and cooperatives. Therefore the purpose of this study is to utilize the business potential of agricultural products from female farmers in East Java Province optimally to empower the economic community in the region that develops agricultural business through technology-based relational marketing to improve marketing performance.

\section{METODE}

This study was designed as explanatory research because it aims to explain the effect of cause and effect relationships among variables in research problems that have been clearly identified (Zigmund, 1997: 39-41). This study aims to explain the relationship between variables, namely perceived ease of use towards Perceived usefulness, social benefits, confidence benefits, special treatment benefits, satisfaction and usage intention. KWT conducts online product sales in East Java. The type of data in this study is cross-section data, namely data retrieval at a certain time rather than long term (longitudinal).

Identification of the development of information technology-based relational marketing models that take place in the area of research objects including identification of determinants of supporting factors and inhibitors of the implementation of information technology-based relational marketing. The design of this study uses action research models such as participatory action research, action research diagnosis and empirical action research (Kemmis and Taggart, 1988). In addition to the high level of scholarship, this type of research 
was chosen also in accordance with the objectives of the study, namely to produce a relational marketing model that can be a reliable model in improving the marketing performance of the area studied.

In the need assessment phase, a focus discussion group method will be used. This method is very good for extracting data from industry and trade service officials because with this method they can express their opinions openly and in groups. However, in the implementation of this focus discussion group, researchers (guides) must be able to propose problem questions in a way that is understandable and in accordance with the respondents (Muthir. 1991).

\section{Object}

The object of this research is (1) women farmers (2) farmer women who manage further agricultural products or sell still from agricultural products without further management. Who already sells by further processing how the marketing system. both who do marketing online through facebook, WordPress blogs, simple websites until those who are interactive can order online; (3) entrepreneurs who process agricultural products in marketing it has not done online marketing.

Expected results in the first year research; (1) identification of female farmer business (2) identification of development models for women farmers / entrepreneurs who conduct online marketing through facebook, WordPress blogs and websites that are not interactive with customers (still simple not updated regularly); (2) identification of women farmers / entrepreneurs who have not conducted online marketing to develop online marketing.

The research subjects in the first year were female farmers who had processed agricultural products and who had done online marketing or who had not done online marketing, elements of the industrial and trade and service agencies, paranoia service, cooperative services and other related agencies tasked with developing empowerment female farming community, cooperative in the research area.

\section{Data Collection Techniques}

The technique used to collect data is to focus on group discussion, observation and documentation. The focus of group discussions supported by interviews was used to identify the interests and needs of the community of female farmers and residents of surrounding communities in the research area.

Observation is used to observe the conditions and potential that can be developed through marketing agricultural products online as a means of increasing community economic empowerment-oriented towards improving marketing performance in the research area.

The documentation method is used to capture data relating to the data stored in documents at the Department of Trade and Industry, the Department of Agriculture, the Office of Cooperatives in Blitar District to support the research process.

\section{Sampling Techniques}

Determination of the sample to explore data in this need assessment, determined by the industrial service and trade as a service that is directly related to the process of economic empowerment of women farmers, in the Mojokerto Regency government environment. For this reason, the key person will be started at the Blitar Regency industrial and trade service and snowball based on the recommendations of the key person. Other officials, peasant groups included in the SME group and agricultural women's cooperatives, determined several people 
be actively involved in discussion group forums, as well as the methods specified in this study. With this method, it is expected to produce a prototype of an information technology-based relational marketing model in the area under study.

\section{Data Analysis Technique}

Data analysis was carried out using an approach, namely a qualitative approach. Qualitative data is analyzed by basing on logical thinking. From the object of the study, a comparative descriptive analysis was conducted to obtain general conclusions, from the performance of information technology-based relational marketing models developed in the study area. The analysis technique used in this study is an interactive model analysis as developed by Miles and Huberman (1984) which consists of 3 (three) components of analysis, namely data reduction, data presentation, and conclusion drawing. Reduction data is the initial step of analysis to find the data that is most relevant to the research problem. These data are then displayed in the form of tables with frequency distribution models with the intention that they are easily understood which will then be analyzed based on relevant social theory. While descriptive statistics use the percentage formula and mean formula, namely to analyze data from the results of need assessment.

\section{RESULTS AND DISCUSSION}

The results of this study include 2 things, namely as follows:

\section{Product Classification}

Product management includes developing tactics and strategies to increase market demand through the product life cycle.

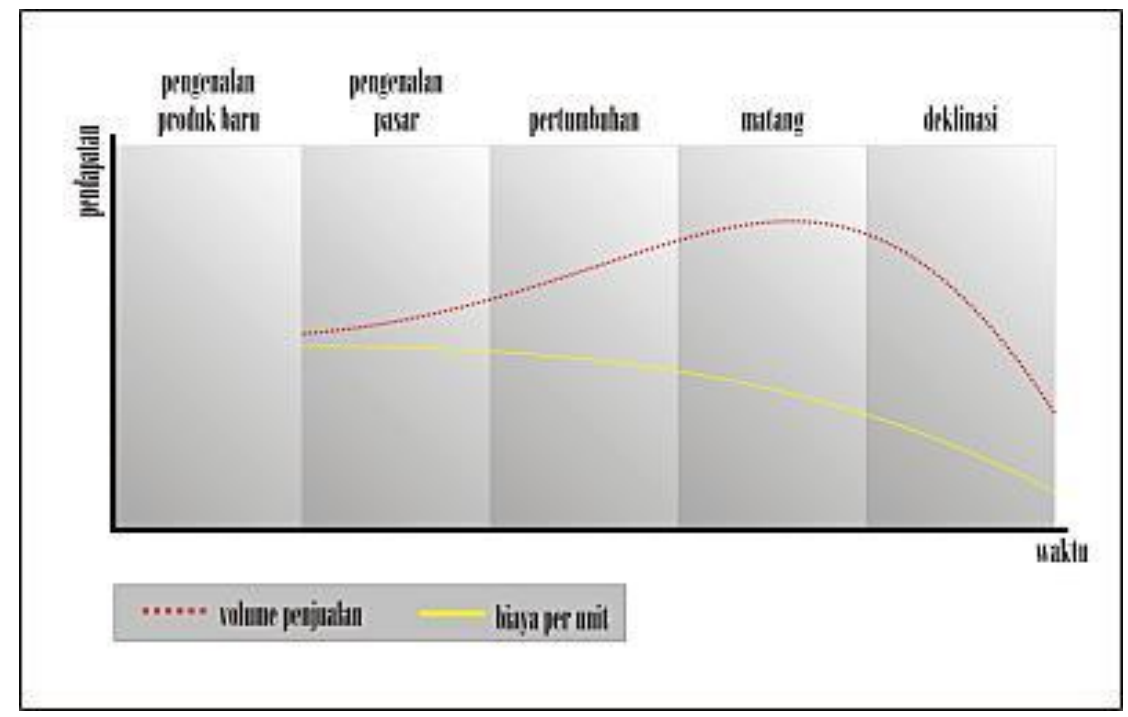

Gambar 6. Tahapan Siklus Hidup Produk

\section{Product Life Cycle Management}

The level of product sales will change over time. The product life cycle refers to the stages that the product will pass. The product life cycle is a set of strategies implemented by management in the face of the cycle.

Products generally have a tendency to go through five stages:

1. Stage of introducing new products
a. Prices are very expensive
b. There is no sales revenue yet
c. Loss 
2. Market introduction phase
a. The cost is very high
b. Expensive price
c. Small sales volume

\section{Stage of growth}
a. Costs have decreased with increasing production volume
b. Sales volume experienced a significant increase
c. Receiving benefits
d. Price adjustment to maximize market share

4. Mature stage
a. Very low-cost
b. Sales volume reaches the optimal point
c. Decreased prices along with the growth in the number of competitors
d. Experience the peak point of achieving profit

\section{Declination stage}
a. Sales volume has decreased
b. The popularity of products has declined

\section{Differentiated Products}

Product differentiation is the activity of modifying a product to make it more attractive. This differentiation requires market research that is quite serious because in order to be truly different, knowledge of competing products is needed. Differentiation of this product usually only changes the character of the product, including packaging and promotional themes without changing the physical specifications of the product, even if it is permissible. The purpose of the differentiation strategy is to develop the right positioning according to the wishes of potential consumers who want to be addressed. If the market sees the difference in your product compared to competing products, you will find it easier to develop a marketing mix for that product. Successful product differentiation is differentiation that is able to shift the basis of competition from price to other factors, such as product characteristics, distribution strategies or other promotive variables. The disadvantage of differentiation is the need for additional production costs and massive advertising.

From the results of this study, it can be conveyed the form of readiness of women farmer groups in marketing their products as follows:

Make a product that is unique and has advantages over other similar products.

Competitors are everywhere if the product or service offered does not have advantages, it will be difficult to compete. Quality products alone are not enough, the product must also meet consumer needs. Along with the times and technology, of course, consumer needs also change, if the product is slow in innovating, it will be left behind by competing products.

\section{Close to existing customers and continually get new customers.}

In developing a small business, you must constantly look for new customers, as well as how to create a pleasant atmosphere for existing customers. Be a customer friend, serve with friendliness, otherwise they will talk negatively about our products. Attracting existing customers can be done by giving something for free to customers, in return for being loyal to us, in this way we can always connect with customers. 
Humans have limited memory, most likely customers will forget our products. Finding the best ways to attract new customers in small businesses can be done as follows:

1) Join social networks such as (Facebook, Instagram, line, path, Wa, Dsb).

2) Offer free products as product tester or endorse.

3) Encourage our prospective customers to provide information about our products.

\section{Utilizing e-commerce in marketing the products of women farmer groups or internet marketing}

Is a means of promoting products through the internet, by utilizing e-commerce, businesses have the opportunity to reach a broad market even globally. E-commerce in the business world can support the cutting of the distribution chain so that consumers can get a product at a low price. Product marketing with e-commerce has several benefits, including cheap and efficient, and has unlimited access, and shortens the distance of product distribution.

\section{Arrange the right "marketing message" when promoting a product.}

The right marketing message is very important to get attention from prospective customers, the way is as follows:

1) Make a marketing message that describes the uniqueness and attractiveness of products that make prospective customers loyal.

2) Adjust marketing messages to the problems faced by potential customers so they will pay attention.

3) Use the impression of smart marketing, both in meetings, telephone, correspondence and on the website.

\section{STP (Segmenting, Targeting, Positioning)}

1) Segmenting is the process of placing consumers in subgroups in the product market, therefore segmentation is an identification process that aims to get buyers in the entire market.

2) Targeting (determining the target market) is Determining the existing target market is a marketing strategy so as not to sell the wrong product to the wrong person. added differentiation compared to its competitors.

3) Positioning (positioning strategy) is a combination of marketing activities carried out by management to meet the needs and desires of each target market. This strategy consists of supporting product and service components, distribution, prices and promotions.

\section{Improve Product Quality.}

The application of quality improvement as a business strategy emphasizes three main requirements for management and workers.

\section{Distribution strategy.}

Relationships with buyers in the target market will occur in the form of direct relationships and networks of marketing intermediaries (such as wholesalers, retailers). The need for distribution channels is increasing to connect producers with end users and business markets. Decision making to use distribution channels concerns the type of channel that will be used. Channel selection is distributed to influence brand positioning in the minds of consumers.

\section{Pricing strategies.}

Price is one very important part of marketing a product because the price is one of the 4 marketing or marketing mixes. So price is an exchange rate of goods and services products expressed in monetary units. Price is one of the determinants of the success of a business 
because prices determine how much profit the company will get from selling its products. In setting a price if it is too high it will cause sales to decrease, but if the price is too low it will reduce the profits that can be obtained by the business owner.

Prices also help determine product positioning, consumer reactions to alternative prices, product costs, competitor prices, and other legal and ethical factors improve management flexibility in pricing. The strategy for choosing a role in positioning includes determining the position of the product or brand that is desired, including the obstacles needed to satisfy and motivate suppliers.

Prices may be used as a component of a real marketing strategy or even a marketing emphasis might be on other marketing mix components. Price becomes something that is quite sensitive for customers, one of the considerations in building a marketing strategy is determining the right price. The price is estimated from the materials obtained and also does not take too much profit. The benefits obtained by working mothers are greater than sales, while for materials only get a little more profit.

\section{Promotion Strategy}

Promotion is real and conscious efforts to carry out socialization, information, and notification to the public about various information, which is usually about various products offered. Promotion is an effort of marketing in informing and influencing other people or parties so that they are interested in making transactions or exchanging products or services that are marketed. As for promotion goals are:

1) Disseminate product information to potential target markets.

2) To get an increase in sales and profits.

3) To get new customers and maintain customer loyalty.

4) To maintain the stability of the seller when it becomes sluggish in the market.

5) Differentiate and favour products compared to competing products.

6) Form a product image that is in the eyes of consumers in accordance with what is desired.

Promotional activities carried out by the owners of the Joint Kenanga business group are basically nonexistent, only because they prioritize reasonably priced prices, besides that it is expected that word of mouth of buyers or consumers can be a cheaper, faster and more effective promotional tool in the following ways:

1) Always supervise every production process

2) Maintaining the quality of the product taste

3) Always innovating to create new product results

4) Always listen to input from consumers

\section{CONCLUSION}

Based on the results of observations and interviews conducted, conclusions that can be taken from the results of the research that have been done are as follows:

1. The district KWT where the research is located in the Blitar area of $55 \%$ still uses the marketing mix (4P concept). For promotions, still using promotions through advertising or building relationships with customers as a conventional form of marketing communication. They do not use Customer Relationship Management to obtain, maintain and develop profitable customers.

2. Farmer groups in Blitar around $20 \%$ use information technology to promote and sell their products, for example with social media, blogs or the web. The use of this 
technology based on our observations is as simple as there are no special employees who are tasked to promote online so that the product or price is not updated properly.

3. The groups of women farmers in the area of about $30 \%$ who have used information technology to promote and sell their products, for example with social media, blogs or the web. The use of technology has been done professionally. There is a special employee whose job is to promote online so that the product or price is updated properly. And this group of women farmers who often attend invitations from the Cooperative Office and the Ministry of Industry and Trade when invited.

\section{Reference}

Dinas Koperasi dan UMKM Provinsi Jawa Timur. Laporan Kinerja Dinas Koperasi dan UMKM Provinsi Jawa Timur Triwulan 4 tahun 2011. Sidoarjo: Dinas KUMKM, 2011

Kemmis, S \& Mc Taggart, R. 1988. The Action Research Planner. Australia: Deakin University Press.

Miles, M.B \& Huberman A.M. 1984, Analisis Data Kualitatif. Terjemahan oleh Tjetjep Rohendi Rohidi. 1992. Jakarta: Penerbit Universitas Indonesia.

Sri-Nuryani,. 2012. Serapan Hara N,P dan K pada Tanaman Padi dengan Berbagai Lama Penggunaan Pupuk Organik pada Vertisol Sragen. Jurnal Ilmu Tanah dan Lingkungan. 12 (1): 1 - 13.

Zikmund, William G., 1997. Business Research Methods. USA: Dryden Press. Hill, New York. 